\title{
UNDERGROUND RADIONUCLIDE MIGRATION AT THE NEVADA TEST SITE
}

\author{
Gregory J. Nimz \\ Lawrence Livermore National Laboratory \\ Joseph L. Thompson \\ Los Alamos National Laboratory \\ Members of the \\ Hydrology and Radionuclide Migration Program \\ of the Department of Energy-Nevada Field Office
}

June 22, 1992

This is an informal report intended primarily for internal or limited external distribution. The opinions and conclusions stated are those of the author and may or may not be those of the Laboratory.

Work performed under the auspices of the U.S. Department of Energy by the Lawrence Livermore National Laboratory under Contract W-7405-Eng-48. 


\section{DISCLAIMER}

This document was prepared as an acccount of work sponsored by an agency of the United States Government. Neither the United States Government nor the University of California nor any of their employees, makes any warranty, express or implied, or assumes any legal liability or responsibility for the accuracy, completeness, or usefulness of any information, apparatus, product, or process disclosed, or represents that its use would not infringe privately own rights. Reference herein to any specific commercial products, process, or service by trade name, trademark, manufacturer, or otherwise, does not necessarily constitute or imply its endorsement, recommendation, or favoring by the United States Government or the University of California. The views and opinions of authors expressed herein do not necessarily state or reflect those of the United States Government or the University of California, and shall not be used for advertising or product endorsement purposes.

This report has been reproduced directly from the best available copy.

Available to DOE and DOE contractors from the Office of Scientific and Technical Information

P.O. Box 62, Oak Ridge, TN 37831

Prices available from (615) 576-8401, FTS 626-8401

Available to the public from the National Technical Information Service

U.S. Department of Commerce 5285 Port Royal Rd.

Springfield, VA 22161

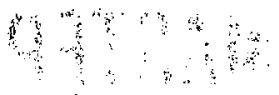




\section{DISCLAIMER}

Portions of this document may be illegible in electronic image products. Images are produced from the best available original document. 


\title{
UNDERGROUND RADIONUCLIDE MIGRATION AT THE NEVADA TEST SITE
}

\author{
Gregory J. Nimz \\ Nuclear Chemistry Division \\ Lawrence Livermore National Laboratory \\ and \\ Joseph L. Thompson \\ Isotopes and Nuclear Chemistry Division \\ Los Alamos National Laboratory \\ Members of the \\ Hydrology and Radionuclide Migration Program \\ of the Department of Energy - Nevada Field Office
}

$6 / 22 / 92$

\begin{abstract}
This document reviews results from a number of studies concerning underground migration of radionuclides from nuclear test cavities at the Nevada Test Site (NTS). Discussed are all cases known to the Department of Energy's Hydrology and Radionuclide Migration Program where radionuclides have been detected outside of the immediate vicinity of nuclear test cavities that are-identifiable as the source of the nuclides, as well as cases where radionuclides might have been expected and were intentionally sought but not found. There are nine locations where source-identifiable radionuclide migration has been detected, one where migration was purposely induced by pumping, and three where migration might be expected but was not found. In five of the nine cases of non-induced migration, the inferred migration mechanism is prompt fracture injection during detonation. In the other four cases, the inferred migration mechanism is groundwater movement. In only a few of the reviewed cases can the actual migration mechanism be stated with confidence, and the attempt has been made to indicate the level of confidence for each case. References are cited where more information may be obtained. As an aid to future study, this document concludes with a brief discussion of the aspects of radionuclide migration that, as the present review indicates, are not yet understood. A course of action is suggested that would produce a better understanding of the phenomenon of radionuclide migration.
\end{abstract}




\section{INTRODUCTION}

Since 1962 there have been more than 600 nuclear devices detonated underground at the $3600 \mathrm{~km}^{2}$ Nevada Test Site ${ }^{1}$. About $30 \%$ of the tests were at or below the standing water level. The potential for adverse effects on the groundwater is clear. The lack of plentiful water in southern Nevada makes all groundwater in the region especially valuable. Although the demand for water is currently light in the sparsely populated NTS area, no one can foresee future water demands. Further, no one is willing to jeopardize the present water supply required for NTS operations, which includes drinking water. Thus even though the water table is very deep (400 to 700 meters) and the hydraulic conductivities generally low (1 to 100 meters/year), there is great concern on the part of the Department of Energy that, in so far as possible, groundwater not be contaminated by Nevada Test Site activities. The DOE-Nevada Field Office has adopted a groundwater protection policy 2 that is designed to minimize the impact of nuclear testing on the environment. As a starting point for implementation of this policy, the present quality of groundwater on the NTS must be understood. Also, because there are very few places in the world where field studies of radionuclide migration can be conducted, the NTS is a particularly valuable resource for research purposes. Here there are a large number of radionuclide sources which have been in contact with groundwater for varying periods of time and in several different geologic and hydrologic environments. Information gained from studying groundwater contamination at the NTS will have relevance both for the local situation and for national and international programs dealing with radioactive and other waste storage.

Our present knowledge concerning radionuclides in NTS groundwater comes from several sources. The Hydrology and Radionuclide Migration Program (HRMP) has conducted several studies over the past 17 years designed to yield information on radioactive materials in both soil and water near nuclear test locations. The HRMP has drilled three wells at nuclear test locations for the designed purpose of characterizing the processes that control radionuclide migration; it has also analyzed water from several post-shot exploratory holes within and adjacent to test cavities. Both the Lawrence Livermore and Los Alamos National Laboratories drill exploratory, emplacement, and pre-shot satellite holes in areas that have been heavily used for testing. Samples from these holes are tested for radionuclides during drilling, and water samples are occasionally taken by the U.S. Geological Survey (USGS) and the Desert Research Institute (DRI) for radiochemical analysis. However, there has been no systematic program for the USGS or DRI sampling. The U.S. Environmental Protection Agency (EPA) and Reynolds Electrical and Engineering Company (REECo) periodically monitor water from water supply wells currently in use at the NTS, as well as from numerous other sampling points on and adjacent to the NTS. For information on the EPA and REECo monitoring results, particularly concerning tritium concentrations which are not the focus of this document, the reader is referred to the Nevada Operations Office Site Environmental Report. ${ }^{3}$

Information from the above programs has been used to prepare this review of instances in which radioactive material has been detected outside of the immediate vicinity of nuclear test cavities that are identifiable as the source of the nuclides. Locations of all of the sites discussed in this document can be found on Figure 1. Excluded from discussion in this paper are instances in which tritium alone has been detected in NTS water and its probable source could not be identified. Tritium, being an isotope of hydrogen, is likely to migrate readily with moving groundwater and become dispersed. This possibility can make it difficult to identify a specific nuclear test as a tritium source and therefore to determine the actual migration distance. Because of this, this paper addresses tritium only in instances where there appears to be justification for identifying its source and migration distance. In 
a final section, this paper reviews instances where migration might be expected and has been sought but not found. Before discussing these migration and non-migration cases, it may be well to gain some perspective on the phenomenon of radionuclide migration itself by discussing the terminology used, the significance of the quantities involved, and the inferred mechanisms of migration. For a more extensive description of the NTS environment and the basic phenomena associated with underground nuclear testing, the reader is referred to reference 4.

\section{Terminology, Units and Relative Quantities, and Migration Mechanisms.}

The levels of radioactivity measured are generally in the range of picocuries per gram (pCi/g) or milliliter (ml). A picocurie is $10^{-12}$ curies, or 2.22 disintegrations per minute. A gram of NTS volcanic tuff will typically contain about $20,000 \mathrm{ppm}$ potasium, $4 \mathrm{ppm}$ uranium, and $20 \mathrm{ppm}$ thorium. 5 The natural radioactivity in a gram of NTS tuff is about 30 pCi of ${ }^{40} \mathrm{~K}$ and about $20 \mathrm{pCi}$ each of uranium (+ daughters) and thorium (+ daughters). Groundwater also contains natural radioactivity. A milliliter of average groundwater may contain $0.01 \mathrm{pCi}$ of dissolved ${ }^{40} \mathrm{~K}$ and up to $1 \mathrm{pCi}$ of tritium, although the general tritium background level at the NTS is below $0.01 \mathrm{pCi} / \mathrm{ml}$. Water containing up to $20 \mathrm{pCi} / \mathrm{ml}$ of tritium is considered safe for drinking. These natural levels of radioactivity, though small, are readily detectable with modern instrumentation.

A nuclear test may produce curies of fission products, most of which are incorporated in the molten rock which solidifies as "melt glass" near the bottom of the cavity. 4 Certain volatile fission products may become deposited on the walls and ceiling of the cavity. Gaseous products may diffuse into the surrounding rock. If water flows into the cavity, some fission products will dissolve into the water. The nuclides within the melt glass will leach out slowly over many years. Some fission products which would otherwise be soluble will instead sorb onto rock surfaces in and near the detonation cavity. 5 In general, only those radioactive elements which are dissolved as neutral species (e.g., ${ }^{85} \mathrm{Kr}$ and tritium as water) or those which are anions (e.g., $36 \mathrm{Cl}$ and $99 \mathrm{Tc}$ ) move through tuffaceous rock, such as that at the NTS, without appreciable sorption. The result of all these processes is that a multi-curie source term may not produce much radioactivity in groundwater that would migrate from the cavity. Further, after several years there will typically be less than about ten fission products remaining in detectable concentrations from a nuclear test; those with short half-lives will have decayed away. This further reduces the long-term hazard of water from a nuclear test cavity.

As will be seen below in the discussion of specific NTS study sites, the mechanism(s) by which radionuclides migrate is a critical issue that cannot as yet be determined in every case. Clearly, groundwater is capable of carrying certain dissolved nuclides appreciable distances. It is theoretically possible, although as yet undocumented, for certain sorbing nuclides to be transported attached to colloidal particles in the water. An association between sorbing nuclides and colloids has been documented on the NTS ${ }^{7}$, but in this instance migration of the colloids themselves could not be established with certainty and thus radionuclide migration by a colloid mechanism was not established. For relatively short (but as yet unknown) distances, nuclides can be injected into fractures surrounding the nuclear test cavity at the time-of detonation. The enormous pressures generated during a nuclear test may create fractures or open pre-existing fractures in the surrounding rock. Because the groundwater may also preferentially move through these fractures, it can be 
difficult to accurately determine whether the mechanism for radionuclide migration was groundwater movement or fracture injection.

In the migration cases listed below, the attempt has been made to identify the primary migration mechanism involved. Except for four cases (RNM-2S, UE4g\#2, U9TTS-U-29, and the rock core from $\mathrm{U} 3 \mathrm{cn} 5$ ), there are no instances where the migration mechanism seems clear. In certain of the cases, however, there is circumstantial evidence for one mechanism or another. For the purpose of exposition in this paper, these circumstantial cases are classified under the same categories as the more clearly established cases, although in each case the attempt was made to clearly state the level of certainty of the migration mechanism.

\section{Locations Where Movement of Radionuclides Has Been Observed.}

\section{A. Inferred Mechanism: Prompt Fracture Injection.}

1. U3cn5 (rock core from during drilling): Radioactivity was detected in rock cores and wells logs in U3cn5, a satellite hole drilled 122 meters from ground zero of the Bilby event (U3cn), the first nuclear test detonated below the water table 8,9 . U3cn5 was drilled two years after detonation. Based on data from a Bilby re-entry hole (U3cnPS2), the Bilby chimney had not yet re-filled with water. 10 Water movement at this time was toward the cavity. ${ }^{7}$ The radioactivity encountered in $U 3 \mathrm{cn} 5$ therefore could not have been transported from the cavity by normal groundwater movement, but must have been injected through fractures during the detonation. The injection distance is fairly small, about 60 meters from the calculated edge of the cavity. ${ }^{9}$

2. UE4g\#2: This exploratory hole was drilled 15 meters east of the emplacement hole $\mathrm{U} 4 \mathrm{~g}$, which was later to be the site of the nuclear test Iceberg. Core material from UE4g\#2 contained tritium and several fission products. ${ }^{11}$ The probable source was identified as the Latir test (U4d) detonated four years earlier 320 meters to the northwest. Because of the strontium to tritium ratio in the core material, it has been argued that the transport was by gaseous krypton precursors. ${ }^{12}$ The magnitude of the ${ }^{89} \mathrm{Sr} / 90 \mathrm{Sr}$ ratio further suggested that the movement occurred no more than minutes after the Latir detonation. ${ }^{13}$ These two facts make prompt injection the likely migration mechanism.

3. U9ITS-U-29: This emplacement hole was found to contain 192 Ir and a number of fission products in fractures at about 220 to 230 meters depth 14 . The origin of this material was believed to be an event detonated two months earlier at U9ITS-T-28, 172 meters away. Gamma logging, TV scanning, and sidewall sampling were used to associate the fractures and the radioactive material. Two auxiliary holes were drilled in the vicinity of U9ITS-U-29. UE29\#2, drilled between U-29 and T-28, yielded core with ${ }^{137} \mathrm{Cs}$. UE29\#1, drilled at a different orientation, yielded no activity. The facts that the radioactivity was located well above the standing water level and that it had gotten there in a short amount of time imply a prompt injection migration mechanism rather than water transport.

4. U3kz: During dewatering in $\mathbf{1 9 8 5}$ of the emplacement hole U3kz for the Aleman test, the water was found to contain tritium in concentrations around $10^{4} \mathrm{pCi} / \mathrm{ml} .15$ Fission products ${ }^{85} \mathrm{Kr},{ }^{106} \mathrm{Ru},{ }^{125} \mathrm{Sb}$, and ${ }^{137} \mathrm{Cs}$ were also detected. Ratios of rhodium isotopes enabled the source to be identified as the Sandreef event (U7aq) conducted eight 
years earlier 350 meters away. 16 Exploratory holes UE3e\#1, UE3e\#2, UE3e\#4 drilled between $\mathrm{U} 3 \mathrm{kz}$ and $\mathrm{U} 7 \mathrm{aq}$ indicate that the fission products occur in narrow bands (fractures?) in the rock. Tritium concentrations in water samples from these holes correlate well with the fission product concentrations. Laboratory studies of rock cores recovered from UE3e\#4 suggest that the fission products found in UE3e\#4 did not move to that location either as dissolved species or with colloids moving in groundwater.17 On the basis of these studies, fracture injection and not groundwater movement appears to be the migration mechanism. However, because the radioactivity was found within the saturated zone, the possibility of a groundwater migration mechanism cannot be eliminated. Water velocity would have had to be about $35-45 \mathrm{~m} / \mathrm{yr}$, which is quite rapid for this portion of the NTS. However, the required water velocities would be much less if material was injected at least some distance toward U3kz. Also complicating the interpretation is the presence of a highly pressurized hydrologic zone at depth. 18

5. UE2ce: Significant quantities of tritium $\left(10^{4} \mathrm{pCi} / \mathrm{ml}\right)$ and low but measurable amounts of $85 \mathrm{Kr},{ }^{22} \mathrm{Na}$, and ${ }^{90} \mathrm{Sr}$ have been detected in UE2ce, a satellite well drilled into the Paleozoic carbonate aquifer 180 meters from the Nash nuclear test (U2ce). 9 The satellite well was drilled ten years after the Nash event and pumping was intermittent over a seven year period. Although Nash was detonated above the static water level, its cavity likely extends to a depth very near the water. The researchers who reviewed the data from this site concluded that since the cavity does not intersect the water table, the radionuclides present at UE2ce entered the water-bearing zone through injection. 8 They could not, however, eliminate the possibility that there are fluctuations in the water levels sufficient to submerge the existing cavity. Also, it may be possible that nuclides have been transported downward to the underlying watertable by infiltration of surface water through the chimney and cavity. 19 This is one of the two.known cases at the NTS in which the regionally important carbonate aquifer has been affected by radionuclides (the other is UE7ns, described below).

\section{B. Inferred Mechanism: Transport in Groundwater.}

1. RNM-2S: Radionuclide transport in groundwater was induced at this site in an effort to better understand transport mechanisms. The Cambric event (U5e) was detonated in 1965. In 1974, re-entry well RNM-1 was drilled into the cavity and revealed that tritium and fission products from the test still remained in the cavity/chimney complex. ${ }^{20}$ In 1975, the HRMP began pumping water from a satellite well, RNM-2S, 91 meters from the cavity. Two years later, tritium began to appear in the RNM-2S water. Subsequently, low but significant levels of ${ }^{85} \mathrm{Kr},{ }^{36} \mathrm{Cl}^{-},{ }^{129} \mathrm{I}^{-},{ }^{106} \mathrm{RuO}_{4}{ }^{2-}$, and ${ }^{99} \mathrm{TcO}_{4}^{-}$ were also measured in the water. 21 The concentration of tritium rose to a peak in 1981 and has been declining since.9,22 No cations, such as ${ }^{137} \mathrm{Cs}^{+}$or ${ }^{90} \mathrm{Sr}^{2+}$, have ever been observed at RNM-2S, although they are present in the cavity water. The Cambric experiment clearly demonstrates that, provided a sufficient hydraulic gradient is present, groundwater is capable of transporting certain anions and noble gases, species that do not sorb or sorb only weakly onto rock matrices. Cations, which are capable of strong sorption, are not readily transported.

2. U2aw and UE2aw: Tritium at concentrations up to $1 \times 10^{4} \mathrm{pCi} / \mathrm{ml}$ was detected in 1974 in water pumped from emplacement hole U2aw23. No gamma-emitting fission products were detected. Tritium was also detected at this time in an adjacent 
exploratory hole, UE2aw, but in lower concentrations (about $10^{2} \mathrm{pCi} / \mathrm{ml}$ ). Crow 23 suggests that the probable source was the 1967 Commodore event (U2am) conducted 465 meters to the southeast. Commodore was the closest event to U2aw that was detonated beneath the static water level. Crow postulated that the tritium had moved in groundwater through natural and induced fractures. Although there is a small hydraulic gradient that favors movement of groundwater from U2am toward U2aw, water velocities would have had to have been greater than $65 \mathrm{~m} / \mathrm{yr}$, quite rapid for this portion of the NTS. Crow suggests that high flow velocities may have been induced by forces related to the nuclear explosions in the area. Alternatively, it is possible that prompt fracture injection may have transported the tritium at least some of the distance toward U2aw and UE2aw, decreasing the need to call upon rapid groundwater flow velocities.

3. UE2ar: In 1975, tritium concentrations of about $3 \times 10^{2} \mathrm{pCi} / \mathrm{ml}$ were measured in water from exploratory hole UE2ar; the source was thought to be the 1967 Agile event (U2v), 360 meters to the north. 23 In 1986, an archived sample of the water from UE2ar was found to contain both ${ }^{125} \mathrm{Sb}$ and ${ }^{137} \mathrm{Cs}$ in the $10^{-2} \mathrm{pCi} / \mathrm{ml}$ range. ${ }^{24}$ Because ${ }^{137} \mathrm{Cs}$ is a highly sorbing nuclide, its presence in the water supports the belief that the tritium source was fairly close to UE2ar. As with the previous case, Crow ${ }^{23}$ felt that rapid groundwater movement caused the migration. However, again there is no direct evidence when or by what mechanism movement of the radionuclides occurred. Prompt injection may have also played a role at UE2ar.

4. UE7ns: The Bourbon event (U7n) was detonated in 1967 in Paleozoic carbonate rocks approximately 22 meters above the static water level. ${ }^{9}$ It is probable that the cavity intersected the water table. In 1976, satellite well UE7ns was drilled 137 meters from the U7n location. The cased well was perforated so that water could be sampled from approximately the top seventy meters of the pre-shot saturated zone. This depth interval would include the interval presumably reached by the lower extent of the cavity. Low volume pumping took place until 1984. Maximum tritium levels detected during this time were about $3 \mathrm{pCi} / \mathrm{ml}$, about 7 times lower than drinking water standards, but approximately 300 times greater than regional background levels. No other radionuclide contamination was detected in the water. It is significant to note that the tritium levels slowly increased throughout the duration of the low volume pumping. Increasing tritium levels imply migration with groundwater as opposed to prompt injection alone, where activities levels should remain constant. Bourbon-UE7ns marks the second known site on the NTS where the regionally important carbonate aquifer has been affected by radionuclides.

5. UE20n-1: The Cheshire event (U20n) was detonated in 1976 approximately 7 kilometers from the NTS boundary. 9 A re-entry hole drilled that year, U20nPS1-ddh, was intermittently pumped until 1984. UE20n-1 was drilled in 1987 about 100 meters downgradient from the upper sampling point of U20nPS1-ddh, and pumped in 1987 and 1988. 24 Tritium was detected in UE20n-1 at levels comparable to those observed in the cavity water from U20nPS1-ddh. However, the concentration of fission products such as ${ }^{137} \mathrm{Cs}$ was appreciably lower in UE20n-1. Sample filtration studies have indicated that ${ }^{54} \mathrm{Mn},{ }^{60} \mathrm{Co},{ }^{106} \mathrm{Ru},{ }^{144} \mathrm{Ce},{ }^{154} \mathrm{Eu}$, and ${ }^{155} \mathrm{Eu}$ are associated with colloids at Cheshire6, although the migration behavior of the colloids themselves is unknown. Sufficient data are not yet available to conclusively determine whether the radioactivity found in UE20n-1 is due to groundwater migration (with or without colloids) or represents material injected in fractures at the time of the Cheshire event. 25 The fact that tritium activities are similar in water from the cavity and from UE20n-1 while fission product activities are lower in UE20n-1 suggests that transport may be due to groundwater movement. The groundwater 
migration of the fission products would be retarded due to adsorption onto rock surfaces while the migration of tritium would not. Movement by prompt injection alone would not change the relative activities of tritium and fission products. There is also evidence in support of a model that convectively-driven warm water from deeper zones is flowing upward through the Cheshire cavity and chimney and then horizontally through permeable layers. ${ }^{26}$ Cheshire is a significant study site because of the relatively rapid natural movement of groundwater in the region, the indication of colloid transport, and the proximity to the NTS boundary.

\section{Locations With No Indication of Radionuclide Transport.}

A. Emplacement, exploratory and pre-shot satellite holes.

The LLNL and LANL drilling operations include continuous monitoring of the drilling mud for gross beta and gamma radiation as it is returned to the surface. Daily samples of this mud are scanned with greater sensitivity in the laboratory. After drilling is completed, the U.S. Geological Survey often takes water samples for tritium and gamma spectral analysis. The Desert Research Institute occasionally takes water samples for tritium analysis. It is extremely rare for radionuclides to be found in these samples. However, significant amounts of fluids are used downhole for lubrication and cooling during drilling. It is probable that unless a very large amount of radioactive material is encountered, none will be detected in the returned drilling muds since little of this fluid actually represents formation water. Further, it is unlikely that a substantial fraction of the injected drilling fluid is removed from the formations before the USGS or DRI sampling. Thus the lack of detection of radionuclides may be a function of sampling insensitivities rather than an indication that no radionuclides are present in the formation waters.

B. Post-shot exploratory satellite wells.

1. U3cn5 (water): Although core samples and well logs taken during the drilling of Bilby satellite well $\mathrm{U} 3 \mathrm{cn} 5$ indicated that radioactive material was injected into the rock surrounding the Bilby cavity (see section III.A.1.), no radioactivity was ever encountered in the water taken from this well:9. However, water was never sampled from the stratigraphic intervals where the radioactivity was detected. The cased satellite hole allowed water to be drawn only from carbonate units that exist about 80 meters below the cavity. The well was pumped continuously for 2.5 years, then intermittently for the next four years. After six years without pumping, the pump was replaced and pumping was resumed intermittently for another two years. The pump failed in 1981 and has not been replaced.

2. UE4t: The 1986 nuclear test Gascon (U4t) was conducted below the water table. 27 Two months later the satellite hole UE4t was drilled about 170 meters away in order to study a local pressurized aquifer and to look for radionuclide migration. The satellite hole was drilled in three stages and water samples were taken at each interval. No tritium or fission products were detected in these samples. Following packer tests in the hole, two piezometer tubes were installed in 1990. Water samples taken since that time have not contained tritium above background levels. However, these samples were taken near the top of the water column and may not be representative of water in the screened interval near the bottom of the piezometers. Furthermore, although UE4t was drilled with air-foam and dewatered after each stage, it has never been pumped to ensure the removal of all drilling fluids. 
3. RNM-2S: As discussed above, migration of radionuclides appears not to have occurred during the ten year period following the detonation of the Cambric event. The radionuclides eventually observed at RNM-2S were induced to migrate by largevolume pumping of the well. Movement of radionuclides at the Cambric site would not be expected since there is a very small to non-existent hydrologic gradient and the small size of the detonation yield $(0.75 \mathrm{kt})$ would not have produced major geologic or hydrologic disruptions.

\section{Conclusion.}

This paper has reviewed cases in which radionuclides have been detected outside of the immediate vicinity of nuclear test cavities that are identifiable as the source of the nuclides, as well as cases where radionuclides might have been expected but were not found. In five of the nine cases of non-induced source-identifiable migration there is evidence that the migration occurred as the result of injection into existing or event-created fractures at the time of detonation. In only three of these injection cases, however, can this mechanism be inferred with confidence. In four of the nine cases of non-induced source-identifiable migration there is evidence to suggest that the migration may have been due to water movement, although the possibility of at least some migration by injection cannot be eliminated in any of these.

It is apparent from this review of known migration sites that much more information is needed before the phenomenon of radionuclide migration at the NTS can be fully understood and monitoring for migration can be meaningfully conducted. Without understanding how radionuclides migrate it is impossible to predict whether they will migrate, where they will migrate, or how quickly they will migrate. This review has indicated several specific weaknesses in our understanding of the processes of migration. As the Aleman (U3kz, UE3e\#1, UE3e\#2, and UE3e\#4) case demonstrates, the distances that radioactive material can be injected into the area surrounding a cavity must be determined in order to clearly discriminate between injection and groundwater-related migration. The mechanisms by which radionuclides might migrate within groundwater are also not yet understood; for example, the Cheshire (UE20n-1) case demonstrates that the importance of colloids to radionuclide migration must be better determined. Further, as the Commodore and Agile (U2aw, UE2aw, U2ar) cases demonstrate, in order to accurately assess the rate at which groundwater is capable of transporting radionuclides, the affect of detonation on the local groundwater regime must be determined. Finally, this review of known migration sites leads to the observation that there have been only a small number of attempts made at the NTS to intentionally look for radionuclide contamination in areas where radionuclides would be expected (that is, e.g., in other than water supply wells) or with methods suitable for the investigation (e.g., in water not affected by drilling fluids). Without well-planned investigations into radionuclide migration occurrences, an understanding of the risks posed by potential radionuclide migration cannot be determined.

The best course of action might be to conduct "before and after" studies at one or more future nuclear tests in order to determine: 1) the pre-test local hydrology, including hydrologic gradients and flow rates (to facilitate placement of post-shot monitoring wells); 2) the effect of the detonation on the local hydrology and the recovery time to pre-test conditions, 3) the maximum distances of prompt injection; 4) the inventory of radionuclides moving with the groundwater, 5) the physical/chemical form of the migrating nuclides (dissolved? colloidal? chemical species?); and 6) the long-term behavior of a migrating plume of contaminated water, including changes in contaminant concentration 
with time and changes in the rate of contaminant movement. Although the financial cost of this investigative program obviously would be quite large, and the required duration would be many years, it seems unlikely that any of the central questions concerning radionuclide migration at the NTS can adequately be answered without such a program.

\section{ACKNOWLEDGMENTS}

We wish to thank William Daniels of Los Alamos National Laboratory, Douglas Duncan of the Department of Energy-Nevada Field Office, Roger Jacobson of the Desert Research Institute, and Kenneth Marsh and Jo Ann Rego of Lawrence Livermore National Laboratory for review comments which substantially improved the content of this document. 


\section{REFERENCES}

1. Bryant, E.A. and Fabrika-Martin, J. (1991) Survey of Hazardous Materials Used in Nuclear Testing; Los Alamos National Laboratory Report LA-12014-MS.

2. "Environmental Protection Policy Statement", US Department of Energy/Nevada Operations Office, Memo from N.C. Aquilina, Manager, dated March 22, 1991.

3. McDowell, E.M. and Black, S.C., eds. (1991) U.S. Department of Energy Nevada Operations Office Annual Site Environmental Report - 1990. Report number DOE/NV/10630-20, Volume 1.

4. Borg, I.Y., Stone, R., Levy, H.B., and Ramspott, L.D. (1976) Information Pertinent to the Migration of Radionuclides in Ground Water at the Nevada Test Site, Part 1: Review and Analysis of Existing Information; Lawrence Livermore National Laboratory Report UCRL-52078.

5. Broxton, D.E., Warren, R.G., Hagen, R.C., and Luedermann, G. (1986) Chemistry of Diagenetically Altered Tuffs at a Potential Nuclear Waste Repository, Yucca Mountain, Nye County, Nevada; Los Alamos National Laboratory Report LA-10802-MS.

6. Thomas, K.W. (1987) Summary of Sorption Measurements Performed with Yucca Mountain, Nevada, Tuff Samples and Water from Well J-13; Los Alamos National Laboratory report LA-10960-MS.

7. Buddemeier, R.W. and Hunt, J.R. (1988) Transport of Colloidal Contaminants in Groundwater: Radionuclide Migration at the Nevada Test Site; Applied Geochemistry 3, pp.535-548.

8. Garber, M.S. and Johnson, R.H. (1967) A Summary of the Lithologic Data, Aquifer Tests and Construction of Hydraulic Test Well U3cn-5, NTS; US Geological Survey Technical Letter NTS-200.

9. Buddemeier, R.W. and Isherwood, D. (1985) Radionuclide Migration Project, 1984 Progress Report; Lawrence Livermore National Laboratory report UCRL-53628.

10. Garber, M.S. (undated) Hydraulic test and quality-of-water data from hole U-3cn PS\#2, Bilby site, Nevada Test Site; USGS publication USGS-474-105.

11. "U4g Data Compendium", Los Alamos National Laboratory internal memo H1-NTS3323 from R.W. Henderson, H-1, dated October 3, 1977.

12. "Analysis of Core Samples from UEAg-2", Los Alamos National Laboratory internal memo CNC-11-79-32, from W.R. Daniels, CNC-11, dated January 22, 1979.

13. "Analysis of Dirt from U4g", Los Alamos National Laboratory internal memo CNC11, from D.C. Hoffman, CNC-11, dated November 11, 1977.

14. "Report of Information Pertinent to U9ITS-U-29", Lawrence Radiation Laboratory internal memo KMO-17-71, from K.M. Ostwald, dated March 29, 1971.

15. Hague, R.S. 91987) Aleman Radionuclide Migration Panel Final Report - January 22, 1987; US Department of Energy/Nevada Operations Office. 
16. Thompson, J.L. and Gilmore, J.S. (1991) Migration of Fission Products at the Nevada Test Site: Detection with an Isotopic Tracer, Radiochem. Acta 52/53, p. 229.

17. Thompson, J.L., (in preparation) Laboratory and Field Studies Relate to the Hydrology/Radionuclide Migration Project October 1, 1990 - September 30, 1991.

18. Thompson, J.L. (1991) Interim Report of the Drilling History and Analysis for Nevada Test Site Hole UE3e\#4; Los Alamos National Laboratory report LA-12042-MS.

19. Tyler, S.W., McCay, W.A., Hess, J.W., Jaconson, R.L., and Taylor, K. (1986) Effects of surface collapse structures on infiltration and moisture redistribution; Desert Research Institute, University of Nevada, Water Resources Center Publication No. 45045.

20. Hoffman, D.C., Stone, R., and Dudley, W.W. (1977) Radioactivity in the Underground Environment of the Cambric Nuclear Explosion at the Nevada Test Site; Los Alamos National Laboratory report LA-6877-MS.

21. Bryant ,E.A. (1991) "Cambric Summary Report", draft manuscript, October, 1991.

22. Thompson, J.L. (1991) Laboratory and Field Studies Related to the Hydrology/Radionuclide Migration Project October 1, 1989 - September 30, 1990; Los Alamos National Laboratory report LA-12100-PR.

23. Crow, N.B. (1976) First Observation of Tritium in Ground Water Outside Chimneys of Underground Nuclear Explosions, Yucca Flat, Nevada Test Site; Lawrence Livermore National Laboratory report UCRL-52073.

24. Buddemeier, R.W. (1988) Hydrology and Radionuclide Migration Program, 19851986 Progress Report; Lawrence Livermore National Laboratory report UCRL-53779.

25. Thompson, J.L. (1986) Laboratory and Field Studies Related to the Hydrology/Radionuclide Migration Project October 1, 1984 - September 30, 1985; Los Alamos National Laboratory report LA-10644-PR.

26. Marsh, K.V. (in press) Hydrology and Radionuclide Migration Program 1989 Progress Report; Lawrence Livermore National Laboratory UCRL report.

27. Hawkins, W.L., Trudeau, D.A., and Mihevc, T.D. (1990) Hydrologic Testing in Exploratory Drill Hole UE4t, Yucca Flat, the Nevada Test Site; in "Proceedings of the 5th Symposium on Containment of Underground Nuclear Detonations, Mission Research Corporation, Santa Barbara, California, September 18-22, 1989", Lawrence Livermore National Laboratory report CONF-89-09163, vol.2 . 